\title{
Nutritional behaviour and beliefs of ski-mountaineers: a semi-quantitative and qualitative study
}

\author{
Caroline Praz ${ }^{1}$, Mélanie Granges ${ }^{2}$, Céline Burtin² and Bengt Kayser ${ }^{3 *}$
}

\begin{abstract}
Background: Endurance athletes are advised to optimize nutrition prior to races. Little is known about actual athletes' beliefs, knowledge and nutritional behaviour. We monitored nutritional behaviour of amateur ski-mountaineering athletes during 4 days prior to a major competition to compare it with official recommendations and with the athletes' beliefs.

Methods: Participants to the two routes of the 'Patrouille des Glaciers' were recruited (A, $26 \mathrm{~km}$, ascent $1881 \mathrm{~m}$, descent 2341 m, max altitude 3160 m; Z, 53 km, ascent 3994 m, descent 4090 m, max altitude 3650 m). Dietary intake diaries of 40 athletes (21 A, 19 Z) were analysed for energy, carbohydrate, fat, protein and liquid; ten were interviewed about their pre-race nutritional beliefs and behaviour.

Results: Despite belief that pre-race carbohydrate, energy and fluid intake should be increased, energy consumption was $2416 \pm 696$ (mean \pm SD) kcal · day ${ }^{-1}, 83 \pm 17 \%$ of recommended intake, carbohydrate intake was only $46 \pm 13 \%$ of minimal recommended $\left(10 \mathrm{~g} \cdot \mathrm{kg}^{-1} \cdot \mathrm{day}^{-1}\right)$ and fluid intake only $2.7 \pm 1.0 \mathrm{I} \cdot \mathrm{day}^{-1}$.

Conclusions: Our sample of endurance athletes did not comply with pre-race nutritional recommendations despite elementary knowledge and belief to be compliant. In these athletes a clear and reflective nutritional strategy was lacking. This suggests a potential for improving knowledge and compliance with recommendations. Alternatively, some recommendations may be unrealistic.
\end{abstract}

Keywords: Endurance activity, Food behaviour, Food beliefs, Pre-race nutrition, Energy intake, Ski-mountaineering

\section{Background}

For endurance activities with high levels of energy expenditure, energy intake is an important variable to be considered when devising strategies for optimizing performance [1-3]. High exercise intensities over prolonged periods imply high carbohydrate $(\mathrm{CHO})$ and also fat oxidation rates [4]. $\mathrm{CHO}$ and fat availability are thus important determinants of energy expenditure and it is paramount that athletes use optimal nutritional strategies, not only to manage intake during races, but also before races, to optimize storage, and after races, to optimize refuelling [2, 3, 5-7]. There exists a plethora of literature on sports nutrition, and several scientific and

\footnotetext{
*Correspondence: bengt.kayser@unil.ch

${ }^{3}$ Institute of Sports Sciences and Department of Physiology, University of

Lausanne, Géopolis, Campus Dorigny, 1015 Lausanne, Switzerland

Full list of author information is available at the end of the article
}

sports organizations such as the American Dietetic Association (ADA), the Dieticians of Canada (DC) and the American College of Sport Medicine (ACSM) [2, 8], the International Olympic Committee (IOC) [9] and the International Society for Sport Nutrition (ISSN) [10, 11] have published recommendations and guidelines on energy intake before, during and after exercise [3]. Paradoxically, there is relative paucity of literature reporting actual athlete nutritional behaviour [12]. Among athletes, actual nutritional behaviour does not always comply with the official recommendations, because of a lack of knowledge [13], mistaken beliefs, lack of interest or motivation, practical problems, or perhaps intuition [14]. Nutrition knowledge and beliefs can influence food behaviour [15], even if the relationship is not necessarily obvious. Improved nutritional knowledge plays a role in the adoption of healthier food habits $[16,17]$ and this is 
likely also the case for sport nutrition. Better insight into actual athlete behaviour and its determinants is of importance for adapting guidelines in view of improving compliance $[18,19]$.

A particular type endurance sport is ski-mountaineering racing, consisting of climbing uphill on alpine skis with the heals unlocked in special pivoting bindings and adhesive skins applied to the gliding surface, alternated by skiing downhill with the skins removed and the bindings in the locked position. What makes this sport particular is that it combines very strenuous activity in different locomotion modes with exposure to altitude hypoxia and temperature extremes. Especially uphill the exercise intensity is high with a large fraction of time spend around the respiratory compensation threshold [20-22]. The most popular and famous ski-mountaineering races are generally team races that can last from 4 to more than $12 \mathrm{~h}$. We previously quantified energy expenditure during a famous Swiss ski-mountaineering race ('Patrouille des Glaciers') and found that it was very high: more than $20 \mathrm{MJ}$ $(4,800 \mathrm{kcal})$ for the shorter race route (distance: $26 \mathrm{~km}$; altitude differences: $+1881 \mathrm{~m}$ and $-2341 \mathrm{~m}$; maximal altitude: $3160 \mathrm{~m})$ and more than $35 \mathrm{MJ}(8,400 \mathrm{kcal})$ for the longer one (distance: $53 \mathrm{~km}$; altitude differences: $+3994 \mathrm{~m}$ and-4090 m; maximal altitude: $3650 \mathrm{~m}$ ) [22].

The goal of the present study was to get a global perspective on pre-race nutritional habits among amateur ski-mountaineers during the 4 days preceding this major multi-hour ski-mountaineering race. Four different aspects were investigated: 1) pre-competition nutritional practice; 2) comparison between practice and recommendations; 3) comparison of food behaviour between participants in longer and shorter races; and 4) knowledge and beliefs about pre-race nutrition.

\section{Methods}

Seventy participants in two multi-hour ski-mountaineering races were recruited for a study about ski-mountaineering racing (Fig. 1). They were healthy and trained skiers, who took part in one of the two racecourses of the 'Patrouille des Glaciers' 2012 [22]. The nutritional part of the study was optional for participants. The Valais cantonal research ethics committee approved the protocol of the study (CCVEM 033/11) and each participant gave informed written consent prior to participation.

\section{Laboratory measurements}

Between 2 and 3 months prior to the race, the subjects came to the laboratory, where anthropometric features, body composition and maximal oxygen uptake $\left(\mathrm{VO}_{2 \max }\right)$ were determined. Body fat percentage was measured by air displacement plethysmography (BodPod, Cosmed, Italy). The subjects performed a maximal running test on a motorized treadmill (HP Cosmos Pulsar, Germany) to determine $\mathrm{VO}_{2 \max }$. After warm-up (3 min at $5.4 \mathrm{~km}$. $\mathrm{h}^{-1}$ ), speed was set at $7.2 \mathrm{~km} \cdot \mathrm{h}^{-1}$ and increased by $1.8 \mathrm{~km} \cdot \mathrm{h}^{-1}$ every $3 \mathrm{~min}$ without breaks between stages up to voluntary exhaustion under strong verbal encouragement. The inclination of the treadmill was $0 \%$. Gas exchange and breathing variables were measured breathby-breath throughout with a metabolic measurement system (Metalyser, Cortex, Germany). The data obtained during the last $30 \mathrm{~s}$ of each step were considered for the analysis. The metabolic system was calibrated prior to each experimental session with a 31 syringe and gases of known composition.

\section{The races}

The 'Patrouille des Glaciers' is the most famous and popular ski-mountaineering race in Switzerland. It is a long duration high altitude team race (teams of three) and consists of two different race routes: race $\mathrm{Z}$ from Zermatt to Verbier (distance: $53 \mathrm{~km}$; altitude differences: +3994 m and-4090 m; maximal altitude: $3650 \mathrm{~m}$ ) and race A from Arolla to Verbier (distance: $26 \mathrm{~km}$; altitude differences: +1881 m and-2341 m; maximal altitude: $3160 \mathrm{~m}$ ).

\section{Food intake}

We asked the subjects to complete food diaries during the 4 days preceding the race. They had to write down everything they ate or drank with as much detail as possible about the quality and quantity of food items consumed. The subjects received detailed instructions and examples to help them to appropriately complete their diaries. The

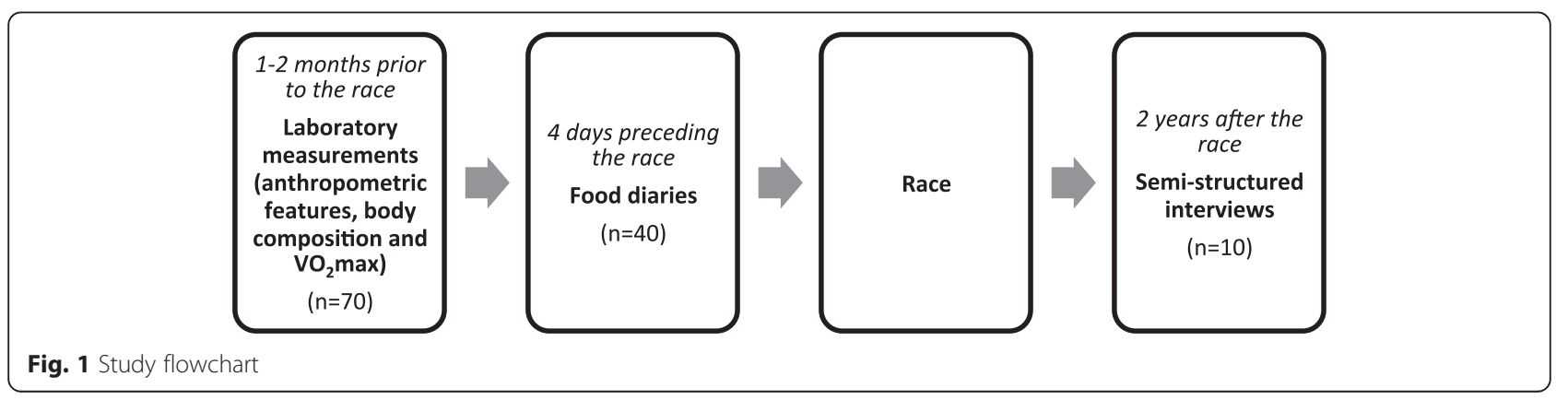


data were analysed with a nutrient analysis software package (Prodi 5.3, Nutri-Science GmbH, Germany).

Fifty-three journals were collected: 13 were eliminated from analysis, because they were incomplete, unclear or unreadable. 40 journals were analysed: 19 were journals of subjects of race $\mathrm{Z}$ (4 women and 15 men, $30 \pm$ 10 years, $176 \pm 7 \mathrm{~cm}, 70 \pm 9 \mathrm{~kg}, 15 \pm 5 \%$ of fat mass, $\mathrm{VO}_{2 \max }: 50 \pm 8 \mathrm{ml} \cdot \mathrm{kg}^{-1} \cdot \mathrm{min}^{-1}$ and 21 of race $\mathrm{A}(6$ women and $15 \mathrm{men}, 40 \pm 7$ years, $176 \pm 7 \mathrm{~cm}, 72 \pm$ $10 \mathrm{~kg}, 18 \pm 8 \%$ fat mass, $\mathrm{VO}_{2 \max }: 58 \pm 8 \mathrm{ml} \cdot \mathrm{kg}^{-1}$. $\left.\mathrm{min}^{-1}\right)$. Energy, macronutrients $(\mathrm{CHO}$, fat and proteins) and liquid intakes were analysed.

\section{Beliefs}

Using the diaries, individual semi-structured interviews were held two years later with a pool of 10 subjects of those with a complete diary. These interviews focused on the beliefs about feeding before the race. There were six main questions: 1) tell me more about the importance that you assigned to nutrition during the preparation for the race; 2) what was your food behaviour during the 4 days preceding the race; 3 ) tell me more about your liquid intake during the 4 days preceding the race; 4) if you were used to consume food supplements, what importance did you assign to these during the 4 days preceding the race; 5) if you were used to consume sports food, which importance did you assign to these during the 4 days preceding the race; and 6) where did you get your information about the nutrition and food strategies you applied? Based on the initial answers to these questions the interviewers asked the participants further questions, to develop and explore details about points that seemed to be especially interesting or needed clarification. Five subjects for each race route were interviewed. We purposely handpicked a diversified sample: three women and seven men, 22 to 56 years, 5 to $37 \%$ of fat mass, $\mathrm{VO}_{2}$ max from 32 to $67 \mathrm{ml} \mathrm{kg}^{-1}$. $\min ^{-1}$ ( $40 \pm 10$ years, $175 \pm 6 \mathrm{~cm}, 70 \pm 11 \mathrm{~kg}, 16 \pm 9 \%$ of fat mass, $\mathrm{VO}_{2} \max : 53 \pm 10 \mathrm{ml} \cdot \mathrm{kg}^{-1} \cdot \mathrm{min}^{-1}$ ).

\section{Statistical analysis}

An ANOVA was used to test whether the four analysed days were similar and to see if pooled mean values could be used for further analysis. For each nutrient the mean and standard deviation values were calculated for the whole population and for the participants in the race $\mathrm{Z}$ and the race A separately. T-tests were performed to verify if there were differences between the participants in the shorter and the longer race. Linear regressions were performed to verify associations between sex, body composition or $\mathrm{VO}_{2} \max$ and aspects of nutritional behaviour. Data were analysed with the software Stata (StataCorp, USA). A $p$-value $<0.05$ was considered significant.

\section{Results}

\section{Food intake and recommendations}

There was no significant difference concerning the main analysed variables (energy, $\mathrm{CHO}$ and drinking intake) between the four analysed days, so the data were pooled and the mean values of the 4 days were used for further analysis. The mean energy consumption was $2416 \pm$ $696 \mathrm{kcal} \cdot$ day $^{-1} \cdot 54 \pm 8 \%$ of the daily energy intake was from $\mathrm{CHO}, 28 \pm 6 \%$ from fat and $18 \pm 5 \%$ from protein (Table 1, Fig. 1). CHO intake was $46 \pm 13 \%$ below the recommended intake levels (10-12 g.body weight $(\mathrm{BW}) \cdot$ day $^{-1}$ ) (Fig. 1). Consequently energy consumption was low too $(83 \pm 17 \%$ of recommended intake (Harris and Benedict.1.8 (low exercise intensity, corresponding to a pre-race tapering period) [2]), but the deficit was limited because fat and protein intake partly compensated the lack of $\mathrm{CHO}$ intake (Fig. 2). The energy intake through fat was $29 \pm 6 \%$ (Fig. 3) of the total daily energy intake (recommendations: between 15 and $30 \%$ ) while protein intake was $100 \pm 28 \%$ of the minimal recommended intake for athletes in daily life $\left(1.3 \mathrm{~g} \cdot \mathrm{kg}^{-1} \mathrm{BW}\right.$. day $\left.^{-1}\right)$. The mean liquid intake was $2.7 \pm 1.0 \mathrm{l} \cdot$ day $^{-1}$ (slightly above recommendations, $1 \mathrm{ml} \cdot \mathrm{kcal}^{-1} \cdot$ day $^{-1}$ in daily life, $2.4 \mathrm{l} \cdot \mathrm{day}^{-1}$ ), partly compliant with the guidelines to already increase the liquid intake before the beginning of a race, without giving a specific amount [23].

One third of the participants took mineral or vitamin supplements. Magnesium was the most commonly used mineral ( $25 \%$ of the participants) while vitamin supplement intake was also frequent (20\% of the participants). 23 participants (58 \%) consumed $\mathrm{CHO}$-rich sports food or drinks, of which $20 \%$ took maltodextrin to increase $\mathrm{CHO}$ intake.

There were few differences between the nutritional behaviour of men and women: men consumed more energy from fat $(p=0.049)$ and tended to consume less energy from $\mathrm{CHO}(p=0.061)$ than women. A higher body fat percentage was negatively associated with

Table 1 Macronutrients: recommendations and declared pre-race consumption by the participants in races Z and A

\begin{tabular}{lccccccccc}
\hline & $\begin{array}{l}\text { Energy intake } \\
\left(\mathrm{kcal} \cdot \mathrm{day}^{-1}\right)\end{array}$ & $\begin{array}{l}\text { Recommended } \\
\text { energy intake } \\
\left(\mathrm{kcal} \cdot \text { day }^{-1}\right)\end{array}$ & $\begin{array}{l}\text { Protein intake } \\
\left(\mathrm{g} \cdot \mathrm{day}^{-1}\right)\end{array}$ & $\begin{array}{l}\text { Recommended } \\
\text { protein intake } \\
\left(\mathrm{g} \cdot \mathrm{day}^{-1}\right)\end{array}$ & $\begin{array}{l}\mathrm{CHO} \text { intake } \\
\left(\mathrm{g} \cdot \mathrm{day}^{-1}\right)\end{array}$ & $\begin{array}{l}\text { Recommended } \\
\mathrm{CHO} \text { intake } \\
\left(\mathrm{g} \cdot \text { day }^{-1}\right)\end{array}$ & $\begin{array}{l}\text { Percentage } \\
\text { of the total } \\
\text { daily energy } \\
\text { from fat }\end{array}$ & $\begin{array}{l}\text { Recommended } \begin{array}{l}\text { percentage of } \\
\text { the tal daily } \\
\text { energy from fat }\end{array} \\
\left(\mathrm{I} \cdot \mathrm{day}^{-1}\right)\end{array}$ \\
\hline Race Z & $2390 \pm 569$ & $2892 \pm 280$ & $86 \pm 22$ & $90 \pm 11$ & $315 \pm 88$ & $694 \pm 86$ & $29 \pm 5 \%$ & $15-30 \%$ \\
Race A & $2428 \pm 314$ & $2948 \pm 494$ & $96 \pm 6$ & $94 \pm 15$ & $329 \pm 28$ & $721 \pm 113$ & $28 \pm 7 \%$ & $15-30 \%$ & $2.3 \pm 0.9$ \\
\hline
\end{tabular}




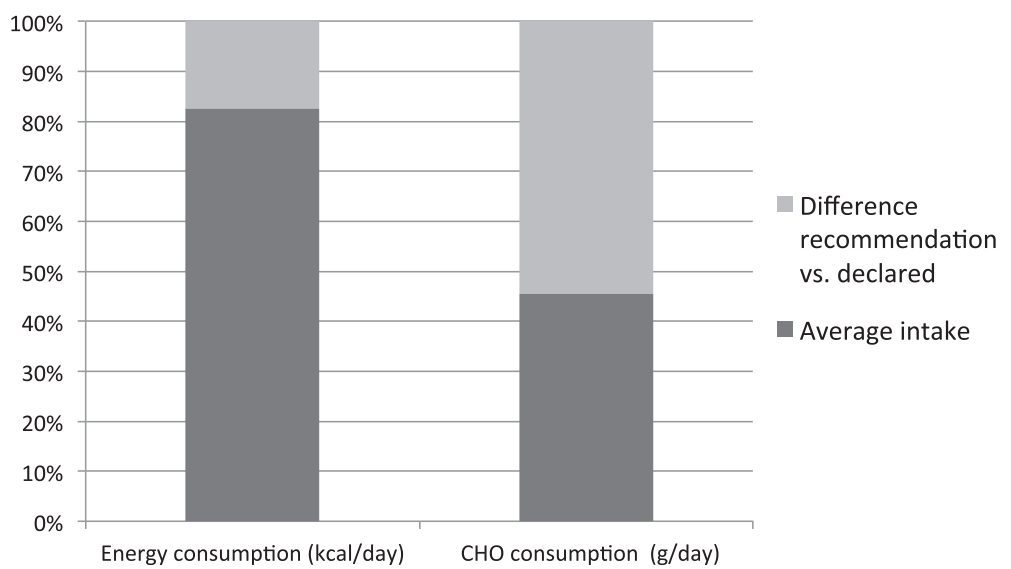

Fig. 2 Average percentage of the daily energy intake from $\mathrm{CHO}$, fat and protein. ACSM guidelines for athletes recommend that $\mathrm{CHO}$ should represent 50 to $70 \%$ of the total daily energy intake, protein between 10 and $35 \%$ and fat between 20 and $35 \%$ [41]

energy intake $\left(R^{2}=0.18, p=0.007\right)$, $\mathrm{CHO}$ intake $\left(R^{2}=\right.$ $0.29, p=0.001)$ and liquid intake $\left(R^{2}=0.19, p=0.010\right)$ (adjusted for gender) and positively associated with the percentage of the daily energy intake form fat $\left(R^{2}=0.14\right.$, $p=0.043)$. A higher $\mathrm{VO}_{2 \max }\left(1 \cdot \min ^{-1}\right)$ was negatively associated with the lipid intake $\left(R^{2}=0.11, p=0.044\right)$.

\section{Comparison of the food intake of the participants in the shorter and the longer race}

No significant differences were noted between macronutrient ( $\mathrm{CHO}$, fat and protein) intake of the participants of races $\mathrm{A}$ and $\mathrm{Z}$; only liquid intake was higher for the participants in race $\mathrm{Z}\left(3.2 \pm 1.0\right.$ vs. $2.3 \pm 0.9 \mathrm{l} \cdot$ day $^{-1}, p=$ 0.005 ( $t$-test, intake adjusted for body mass) (Table 2 ).

Ten of the 19 (53\%) participants in the race $\mathrm{Z}$ used vitamin and/or mineral supplements and 16 (84 \%) consumed sports food. Only one person (5\%) used none. For the participants in the race A, three of the 21 (14\%)

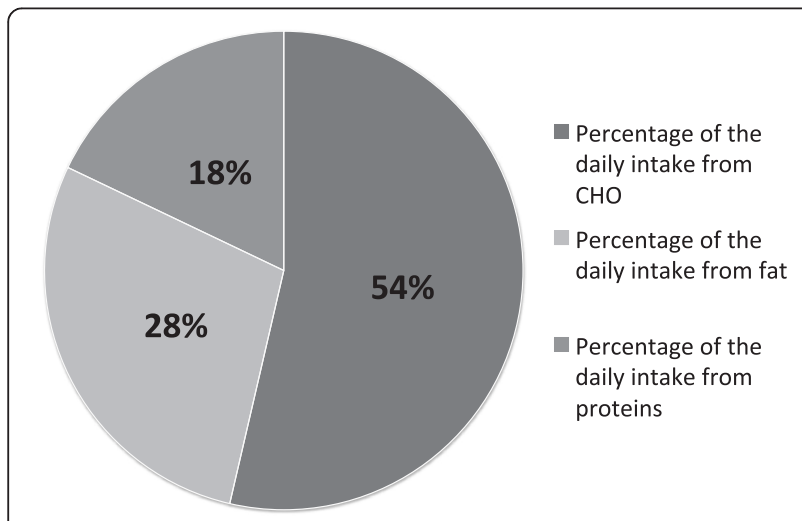

Fig. 3 Comparison recommendation-reality for energy and $\mathrm{CHO}$ consumption. The entire column represents the recommendation (100\%) and the black part the average declared intake for all 40 subjects (in percentage of the recommendation) consumed minerals and/or vitamin supplements and eight (38\%) sports food. Twelve of the 21 participants $(57 \%)$ in the race A took neither supplements nor sports food.

\section{Knowledge and beliefs}

All the interviewed subjects indicated that nutrition during the 4 days preceding a long duration skimountaineering race is relevant for performance. Six of the 10 interviewed subjects found it important or very important while four found it of little or moderate importance. Three common representations could be highlighted in the interviews: 1) during the 4 days before such a race it is good to eat (lots of) pasta to fill up energy stores (all interviewed subjects); 2) during these days water intake has to be increased (9/10); and 3) it is better to eat white meat than red meat $(5 / 10)$.

For the comparison of beliefs with practice, as estimated with the food diaries, we found, on the basis of eight main meals over the 4 days analysed for each subject: 1) On average $4.9 \pm 1.2$ of them included pasta (55\% of meals); these values were $4.4 \pm 1.2$ meals and $61 \%$, respectively, for all 40 subjects; 2) The subjects drank $2.2 \pm 1.4 \mathrm{l} \cdot$ day $^{-1}\left(2.7 \pm 1.0 \mathrm{l} \cdot\right.$ day $^{-1}$ for all 40 participants); 3) For the participants in the race $Z$, who had dinner just before the race (the participants in the race A started in the morning and had breakfast as the last meal before the race): two of the five interviewed subjects ate white meat during the last dinner ( 8 of the 19 participants (42\%) who completed the food journal).

In order to enhance performance and to ensure digestive comfort, some other food items were avoided: four athletes avoided or decreased fat food intake (in particular cheese), three athletes spoke about alcohol avoidance, one of the ten took care not to eat too much and one avoided vegetables and salads. 
Table 2 Supplementation and sports food consumption for each subject from the two race routes

\begin{tabular}{|c|c|c|c|c|c|}
\hline \multicolumn{3}{|l|}{ Race Z } & \multicolumn{3}{|l|}{ Race A } \\
\hline Subject & Supplementation & Sports food & Subject & Supplementation & Sports food \\
\hline 1 & $\begin{array}{l}\text { Vitamin C } \\
\text { Magnesium }\end{array}$ & - & 20 & - & Maltodextrin \\
\hline 2 & $\begin{array}{l}\text { Magnesium } \\
\text { Iron (and vitamins) supplement }\end{array}$ & $\begin{array}{l}\text { MaltodextrinCHO-rich sports drink } \\
\mathrm{CHO} \text {-rich sports cakeProtein shake }\end{array}$ & 21 & Magnesium + vitamin C + L-Carnitin & $\mathrm{CHO}$-rich sports drink \\
\hline 3 & Homeopathic minerals tablets & MaltodextrinCHO-rich sports drink & 22 & - & - \\
\hline 4 & $\begin{array}{l}\text { Magnesium } \\
\text { Calcium }\end{array}$ & $\begin{array}{l}\mathrm{CHO} \text { and protein-rich sports drink } \\
\mathrm{CHO} \text {-rich sports drink }\end{array}$ & 23 & - & Maltodextrin \\
\hline 5 & - & - & 24 & - & - \\
\hline 6 & Multivitamin & $\begin{array}{l}\mathrm{CHO} \text {-rich sports drink } \\
\mathrm{CHO} \text {-rich sports cake }\end{array}$ & 25 & - & $\mathrm{CHO}$-rich sports drink \\
\hline 7 & - & - & 26 & - & - \\
\hline 8 & - & $\mathrm{CHO}$-rich sports drink & 27 & - & - \\
\hline 9 & Multivitamin & $\begin{array}{l}\text { Maltodextrin } \\
\text { CHO-rich sports drink }\end{array}$ & 28 & - & - \\
\hline 10 & - & CHO-rich sports cake & 29 & Magnesium & Maltodextin \\
\hline 11 & - & CHO-rich sports drink & 30 & $\begin{array}{l}\text { Rhodiola rosea } \\
\text { Magnesium }\end{array}$ & - \\
\hline 12 & - & CHO-rich isotonic sports drink & 31 & - & - \\
\hline 13 & - & $\mathrm{CHO}$-rich sports drink & 32 & - & - \\
\hline 14 & $\begin{array}{l}\text { Mutivitamin (+zinc, } \\
\text { calcium, magnesium } \\
\text { and guarana) }\end{array}$ & $\begin{array}{l}\text { Maltodextrin } \\
\text { CHO-rich sports cake }\end{array}$ & 33 & - & - \\
\hline 15 & $\begin{array}{l}2 \text { Multivitamin and } \\
\text { minerals (+caffeine, taurine } \\
\text { and guarana) supplement } \\
\text { Magnesium }\end{array}$ & $\begin{array}{l}3 \text { Protein shakes Protein bar } \\
2 \mathrm{CHO} \text {-rich sports drinks } \\
\mathrm{CHO} \text {-rich bar }\end{array}$ & 34 & - & - \\
\hline 16 & $\begin{array}{l}\text { Amino acids (aspartate } \\
\text { and glutamate) } \\
\text { Omega } 3\end{array}$ & - & 35 & - & - \\
\hline 17 & Vitamin C & Grape sugar & 36 & - & $\mathrm{CHO}$-rich sports drink \\
\hline 18 & - & $\mathrm{CHO}$-rich sports cake & 37 & - & $\begin{array}{l}\text { Maltodextrin } \\
\text { CHO-rich sports bar }\end{array}$ \\
\hline \multirow[t]{3}{*}{19} & - & $\begin{array}{l}2 \mathrm{CHO}-\text { rich sports drinks } \\
\mathrm{CHO} \text {-rich sports cake }\end{array}$ & 38 & - & - \\
\hline & & & 39 & - & - \\
\hline & & & 40 & - & $2 \mathrm{CHO}$-rich sports drinks \\
\hline
\end{tabular}

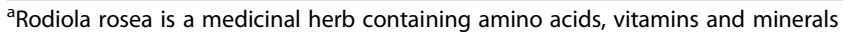

Most of the subjects spoke about food supplements (6/10). Four athletes took magnesium (against muscle cramps (3) or to improve blood flow (1)); one athlete took calcium (also against muscle cramps), one of them spoke about caffeine and one about vitamins. Six indicated that they took sports foods, mostly $\mathrm{CHO}$ drinks $(4 / 10), \mathrm{CHO}-$ rich cake $(2 / 10)$ and maltodextrine $(2 / 10)$, and protein bars and shakes to preserve muscle mass $(1 / 10)$.

The most often quoted sources of information about pre-race nutrition were friends and family $(4 / 10)$, and personal experience and educational background (3/10). Some people got their knowledge from reading $(2 / 10)$, sports coaches $(2 / 10)$, sales representatives of sports food brands $(2 / 10)$, physicians $(1 / 10)$ or pharmacists $(1 / 10)$.

The food journals revealed that vitamin and mineral supplement intake, and sports food consumption was higher than what the interviewed subjects said and remembered (Table 2).

\section{Discussion}

Our intention was to explore 4-day pre-race nutritional habits and beliefs among amateur athletes participating to a major multi-hour ski-mountaineering race. The main findings were that 1 ) the energy and $\mathrm{CHO}$ intake 
was below recommended amounts, while protein and fat intake were close to the recommended intake; 2) the main difference between the participants in the shorter and longer races were liquid, supplement and sports food intakes; and 3) that knowledge and beliefs about pre-race nutrition among these amateur athletes participating to extreme endurance events are insufficient or incorrect.

It is generally believed that high $\mathrm{CHO}$ intake to optimize glycogen storage is the most specific and important recommendation for endurance activity to ensure an appropriate energy supply all along a multi hour endurance race [5]. The $\mathrm{CHO}$ stores (muscle and liver glycogen) are limited and need to be regularly refuelled. $\mathrm{CHO}$ ingestion is thus thought to be very important, whether it is to increase glycogen storage before a workout, during a race to avoid hypoglycaemia and to protect muscle and liver glycogen stores, or after a race to ensure recovery and optimal glycogen resynthesis $[6,7]$. Low muscle glycogen stores during exercise, when accompanied by dropping blood glucose levels can cause performance decreases, subjective feelings of low levels of energy, sensation of heavy legs, excess fatigue, loss of concentration, irritability, dizziness and fainting [7, 24]. So it is important to ensure glycogen store fuelling and refuelling and it is better to start a race with full stores $[6,7]$, especially since the capacity to eat and process food during a race is limited [25]. Current recommendations for $\mathrm{CHO}$ storage before an endurance race are 10 to $12 \mathrm{~g} \cdot \mathrm{kg} \mathrm{BW}^{-1}$. day $^{-1}$, starting 36 to $48 \mathrm{~h}$ prior to the race $[2,9,10]$.

The average $\mathrm{CHO}$ consumption in our population was less than half $(46 \pm 13 \%)$ of these recommended levels and in fact not even a single participant to our study reached them. Given the belief of the interviewed athletes, that high $\mathrm{CHO}$ intake is important prior to such endurance events, this finding is surprising and possibly suggests lack of understanding of the concept of prerace $\mathrm{CHO}$ loading. On the other hand, it may also reflect difficulties in reaching the recommended $\mathrm{CHO}$ amounts just by varying the quantities and proportions of the usual dietary components, without using additional specific $\mathrm{CHO}$-rich sports food to allow the athletes reaching $\mathrm{CHO}$ and total energy-intake values closer to the guidelines. Our observations lead us to ask the question whether today's guidelines are adequate for practical use. The observed average $\mathrm{CHO}$ consumption in our sample was so far from the recommendations that it suggests that it might have been too difficult for our participants to reach the recommendations by consuming twice as much $\mathrm{CHO}$ as they did, even if it were only during the last 24 to $36 \mathrm{~h}$ and not during the full 4 days we looked at.

For the other macronutrients: fat and proteins, there are no specific pre-race recommendations for endurance activities, but there are guidelines for athletes in daily life. Endurance athletes are advised to consume between 1.2 and $1.8 \mathrm{~g} \cdot \mathrm{kg} \mathrm{BW}^{-1} \cdot \mathrm{day}^{-1}$ of protein $[8,9]$ and daily fat intake should amount to 20 to $35 \%$ of total energy intake [2, 8-10]. For these nutrients the intakes of the subjects complied with the guidelines.

Fluid and electrolyte intake are thought to be important for performance because dehydration, when exceeding 2$3 \%$ of body mass, may cause performance impairment [2], even though there is on-going debate on this topic [26]. So it is important to start races in euhydration and to drink enough and frequently during races [8]. Since we only have information about pre-race behaviour and have no data on habitual fluid intake in our subjects we do not know if, according to the recommendations, they increased their fluid intake prior to the race. Intake was on average $2.7 \mathrm{l} \cdot \mathrm{day}^{-1}$, which is slightly above the recommendations for habitual daily intake $\left(2.4 \mathrm{l} \cdot \mathrm{day}^{-1}\right)$ [23]. Also in this case the beliefs of the interviewed athletes contrast with their behaviour since 9 out of 10 mentioned the importance of increasing liquid intake in the last days prior to a major race but only drank an average $2.21 \cdot$ day $^{-1}$.

Although several studies showed that vitamin and/or mineral supplementation does not improve performance during anaerobic [27], strength [28], endurance [28, 29] or ultra-endurance [30] exercise, if the daily diet is adequate [31], supplement intake remains widespread among athletes [30, 32, 33]. In our population, a third of the participants took such supplements. The recommendation is to abstain from vitamin or mineral supplementation if the athlete eats enough and a wide variety of food and in the absence of a known deficit [3]. Additionally, it is important to be careful and to estimate the safety, the efficacy, the potency and the legality of a supplement before taking it $[2,8-10]$. Besides supplements, special sports food consumption was also widespread. Endurance athletes mostly consume special $\mathrm{CHO}$ drinks, gels or bars, which can help reaching the recommendations for energy and $\mathrm{CHO}$ intake [18, 34]. But in spite of $58 \%$ of the 40 participants using $\mathrm{CHO}$-rich sports food or drinks, their $\mathrm{CHO}$ intake remained far below the recommendations.

Digestive comfort is another key variable during endurance events such as multi-hour ski-mountaineering races [35, 36]. Digestive discomfort and gastrointestinal distress like cramps, nausea, vomiting, bloating, and diarrhoea are frequently reported during ultra-endurance activities, particularly during ultra-marathon running [35-37]. To avoid gastrointestinal distress during racing, athletes are advised to avoid dehydration, high-fibre food intake, and hypertonic beverages, and to practice their planned race nutrition strategies before the actual race [36-38]. It is difficult to say from the food diaries which 
food items were specifically avoided during these 4 days, because we do not know the habitual diet of the participants, but from the interviews it seemed that mostly red meat and other fatty food items were avoided.

In general, the athletes seemed to be well aware of the importance of pre-race nutrition for performance. The participants in the longer race $\mathrm{Z}$ placed a more particular emphasis on this topic than the participants to the shorter race A. They also trained more, used lighter racing gear $(12.4 \pm 2.5 \mathrm{~kg}$ vs. $15.4 \pm 3.2 \mathrm{~kg})$ and their supplement and sports food intake was higher. The participants in the longer $\mathrm{Z}$ race were likely more ambitious and experienced athletes, who tried noticeably harder to optimize everything for the race. Our finding of lower lipid consumption by participants with a higher $\mathrm{VO}_{2} \max$ and/or lower body fat percentage, as well as the higher energy, $\mathrm{CHO}$ and liquid consumption of participants with lower body fat percentage also seem in accordance with this contention.

In spite of the declared importance of adequate nutrition in preparation of an endurance event, the knowledge on this topic was approximate. Half of the interviewed participants confused supplementation with sports food; all the participants believed that it is good for them to eat a lot of pasta during the 4 days preceding the race, but rarely spoke about $\mathrm{CHO}$ and other $\mathrm{CHO}$ sources. Moreover, it seemed to be difficult for them to explain why they choose some food items and avoided others. The overall impression was that it rather reflected beliefs than knowledge [15].

The finding in the interviewed athletes that they underestimated their sports food and supplement intake compared to the intake reported in the food journals is probably partly due to the long period of time between the real intake and the interviews. But another important reason for this difference is probably the fact that the athletes did not follow a clear strategy based on solid knowledge. This lack of a clear knowledge and strategy can be a reason for the far too low energy and $\mathrm{CHO}$ consumption.

\section{Limitations}

Our results should be interpreted taking into account some study limitations. Despite participation of 70 subjects to the study we obtained only 40 complete food intake diaries that could be analysed of which $25 \%$ was discussed in detail during the face-to-face semi-structured interviews. The number of observations is therefore limited and not necessarily representative for all amateur athletes participating to the 'Patrouille des Glaciers' and similar extreme endurance events. Also, the interviews were performed two years after the race and obviously some detail may have been lost. However, it is unlikely that the major individual beliefs changed over these two years [39]. The overall strategy, grounded in the personal beliefs was probably close to that of race day. Finally, food diaries are known to be unreliable with frequent under and ill reporting of intake [40], so that our results should be interpreted as semi-quantitative.

\section{Conclusions}

This study about pre-competition nutritional habits and beliefs of amateur athletes before a long duration skimountaineering race showed that: although most of the athletes seemed aware of the importance of nutrition for endurance sports and specifically before a major race, their knowledge was approximate and a clear sound nutritional strategy was missing. Their average $\mathrm{CHO}$ intake represented less than half of the recommended intake, while energy intake was on average $17 \%$ too low. There was no significant difference in the energy and macronutrient intake of the participants in the longer and the shorter race, but participants in the longer race drank significantly more, used more mineral and vitamin supplements and more sports food and drinks.

Taking into consideration all of these issues, some recommendations can be formulated for pre-race nutrition:

1) The athletes should be better informed about nutrition to allow them developing an evidencebased conscious and reflective feeding strategy.

2) A high priority should be given to $\mathrm{CHO}$ intake. The amount should be increased with traditional food (pasta, rice, bread, etc.), completed with $\mathrm{CHO}$-rich sports food and drinks.

3) The chosen pre-race nutritional strategy should be experimented before that prior to the actual race (e.g. before a hard training period or a less important competition) to ensure that it does not cause gastrointestinal distress.

\section{Competing interest}

We have no conflict of interest to declare.

\section{Authors' contributions}

CP participated in study design, data collection (food diaries and interviews) and analysis, and drafted the manuscript. MG and CB participated in study design, the interviews and data analysis. BK participated in study design, data analysis and writing. All authors read and approved the final manuscript.

\section{Acknowledgements}

This study was supported by a grant from the Swiss Federal Office for Sports. We thank Philippe Vuistiner for help with the statistical analysis, and Valérie Ducommun and Maaike Kruseman for their expert help and advice. We are also very grateful to the subjects for their precious time in participating in the study.

\section{Author details}

${ }^{1}$ Institute of Sports Sciences and Department of Physiology, University of Lausanne and Institute for Research in Rehabilitation, SuvaCare Rehabilitation Clinic, Sion, Switzerland. ${ }^{2}$ Nutrition and Dietetics Department, School of Health, University of Applied Sciences and Arts of Western Switzerland, Geneva, Switzerland. ${ }^{3}$ Institute of Sports Sciences and Department of Physiology, University of Lausanne, Géopolis, Campus Dorigny, 1015 Lausanne, Switzerland. 
Received: 22 June 2015 Accepted: 4 December 2015

Published online: 09 December 2015

\section{References}

1. Tosi P, Leonardi A, Zerbini L, Rosponi A, Schena F. Energy cost and efficiency of ski mountaineering. A laboratory study. J Sports Med Phys Fitness. 2010;50(4):400-6.

2. Rodriguez NR, DiMarco NM, Langley S, American Dietetic A, Dietitians of C, American College of Sports Medicine N, et al. Position of the American Dietetic Association, Dietitians of Canada, and the American College of Sports Medicine: Nutrition and athletic performance. J Am Diet Assoc. 2009;109(3):509-27.

3. Potgieter S. Sport nutrition: A review of the latest guidelines for exercise and sport nutrition from the American College of Sport Nutrition, the International Olympic Committee and the International Society for Sports Nutrition. S Afr J Clin Nutr. 2013;26(1):6-16.

4. Romijn JA, Coyle EF, Sidossis LS, Rosenblatt J, Wolfe RR. Substrate metabolism during different exercise intensities in endurance-trained women. J Appl Physiol. 2000;88(5):1707-14.

5. Ormsbee MJ, Bach CW, Baur DA. Pre-exercise nutrition: the role of macronutrients, modified starches and supplements on metabolism and endurance performance. Nutrients. 2014;6(5):1782-808. doi:10.3390/nu6051782.

6. Burke LM, Hawley JA. Carbohydrate and exercise. Curr Opin Clin Nutr Metab Care. 1999;2(6):515-20

7. Burke LM, Hawley JA, Wong SH, Jeukendrup AE. Carbohydrates for training and competition. J Sports Sci. 2011;29 Suppl 1:S17-27. doi:10.1080/ 02640414.2011.585473.

8. American College of Sports $M$, American Dietetic A, Dietitians of C. Joint Position Statement: nutrition and athletic performance. American College of Sports Medicine, American Dietetic Association, and Dietitians of Canada. Med Sci Sports Exerc. 2000;32(12):2130-45.

9. Abstracts of BASES (British Association of Sport and Exercise Sciences) 2011. September 5-8, 2011. Colchester, United Kingdom. J Sports Sci. 2011:29(2):S1-S132.

10. Kreider RB, Wilborn CD, Taylor L, Campbell B, Almada AL, Collins R, et al. ISSN exercise \& sport nutrition review: research \& recommendations. J Int Soc Sports Nutr. 2010;7:7. doi:10.1186/1550-2783-7-7.

11. Kerksick C, Harvey T, Stout J, Campbell B, Wilborn C, Kreider R, et al. International Society of Sports Nutrition position stand: nutrient timing. J Int Soc Sports Nutr. 2008;5:17. doi:10.1186/1550-2783-5-17.

12. Economos CD, Bortz SS, Nelson ME. Nutritional practices of elite athletes. Practical recommendations. Sports Med. 1993;16(6):381-99.

13. Spendlove JK, Heaney SE, Gifford JA, Prvan T, Denyer GS, O'Connor HT. Evaluation of general nutrition knowledge in elite Australian athletes. $\mathrm{Br}$ J Nutr. 2012:107(12):1871-80. doi:10.1017/S0007114511005125.

14. Zouhal H, Groussard C, Minter G, Vincent S, Cretual A, Gratas-Delamarche A, et al. Inverse relationship between percentage body weight change and finishing time in 643 forty-two-kilometre marathon runners. Br J Sports Med. 2011:45(14):1101-5. doi:10.1136/bjsm.2010.074641.

15. Worsley A. Nutrition knowledge and food consumption: can nutrition knowledge change food behaviour? Asia Pac J Clin Nutr. 2002:11 Suppl 3:S579-85.

16. Wardle J, Parmenter K, Waller J. Nutrition knowledge and food intake Appetite. 2000;34(3):269-75. doi:10.1006/appe.1999.0311.

17. Alaunyte I, Perry $\mathrm{J}$, Aubrey T. Nutritional knowledge and eating habits of professional rugby league players: does knowledge translate into practice? J Int Soc Sports Nutr. 2015;12:18. doi:10.1186/s12970-015-0082-y.

18. Jeukendrup A. A step towards personalized sports nutrition: carbohydrate intake during exercise. Sports Med. 2014;44 Suppl 1:S25-33. doi:10.1007/ s40279-014-0148-Z

19. Melin A, Tornberg AB, Skouby S, Moller SS, Faber J, Sundgot-Borgen J, et al. Low-energy density and high fiber intake are dietary concerns in female endurance athletes. Scand J Med Sci Sports. 2015. doi:10.1111/sms.12516.

20. Duc S, Cassirame J, Durand F. Physiology of ski mountaineering racing. Int J Sports Med. 2011;32(11):856-63. doi:10.1055/s-0031-1279721.

21. Schenk K, Faulhaber M, Gatterer H, Burtscher M, Ferrari M. Sk mountaineering competition: fit for it? Clin J Sport Med. 2011;21(2):114-8. doi:10.1097/JSM.0b013e31820f903e.

22. Praz C, Leger B, Kayser B. Energy expenditure of extreme competitive mountaineering skiing. Eur J Appl Physiol. 2014;114(10):2201-11. doi:10. 1007/s00421-014-2939-1.

23. Wolfram G. New reference values for nutrient intake in Germany, Austria and Switzerland (DACH-Reference Values). Forum Nutr. 2003;56:95-7.
24. Jeukendrup A, Brouns F, Wagenmakers AJ, Saris WH. Carbohydrateelectrolyte feedings improve $1 \mathrm{~h}$ time trial cycling performance. Int J Sports Med. 1997;18(2):125-9. doi:10.1055/s-2007-972607.

25. Diamond J. Evolutionary design of intestinal nutrient: enough but not too much. News Physiol Sci. 1991;6(2):92-6.

26. Sawka MN, Noakes TD. Does dehydration impair exercise performance? Med Sci Sports Exerc. 2007;39(8):1209-17. doi:10.1249/mss.0b013e318124a664.

27. Fry AC, Bloomer RJ, Falvo MJ, Moore CA, Schilling BK, Weiss LW. Effect of a liquid multivitamin/mineral supplement on anaerobic exercise performance. Res Sports Med. 2006;14(1):53-64. doi:10.1080/15438620500528323.

28. Singh A, Moses FM, Deuster PA. Chronic multivitamin-mineral supplementation does not enhance physical performance. Med Sci Sports Exerc. 1992;24(6):726-32.

29. Weight LM, Myburgh KH, Noakes TD. Vitamin and mineral supplementation: effect on the running performance of trained athletes. Am J Clin Nutr. 1988;47(2):192-5.

30. Knechtle B, Knechtle P, Schulze I, Kohler G. Vitamins, minerals and race performance in ultra-endurance runners-Deutschlandlauf 2006. Asia Pac J Clin Nutr. 2008;17(2):194-8.

31. Lukaski HC. Vitamin and mineral status: effects on physical performance. Nutrition. 2004;20(7-8):632-44. doi:10.1016/j.nut.2004.04.001.

32. Sousa M, Fernandes MJ, Moreira P, Teixeira VH. Nutritional supplements usage by Portuguese athletes. International journal for vitamin and nutrition research Internationale Zeitschrift fur Vitamin- und Ernahrungsforschung Journal international de vitaminologie et de nutrition. 2013;83(1):48-58. doi:10.1024/0300-9831/a000144.

33. Wiens K, Erdman KA, Stadnyk M, Parnell JA. Dietary supplement usage, motivation, and education in young, Canadian athletes. Int J Sport Nutr Exerc Metab. 2014;24(6):613-22. doi:10.1123/ijsnem.2013-0087.

34. Stellingwerff T. Competition Nutrition Practices of Elite Ultra-Marathon Runners. Int J Sport Nutr Exerc Metab. 2015. doi:10.1123/ijsnem.2015-0030.

35. Stuempfle KJ, Hoffman MD. Gastrointestinal distress is common during a 161-km ultramarathon. Journal of sports sciences. 2015:1-8. doi:10.1080/ 02640414.2015.1012104

36. De Oliveira EP, Burini RC, Jeukendrup A. Gastrointestinal complaints during exercise: prevalence, etiology, and nutritional recommendations. Sports Med. 2014:44 Suppl 1:S79-85. doi:10.1007/s40279-014-0153-2.

37. De Oliveira EP, Burini RC. Food-dependent, exercise-induced gastrointestinal distress. J Int Soc Sports Nutr. 2011:8:12. doi:10.1186/1550-2783-8-12.

38. Ter Steege RW, Kolkman JJ. Review article: the pathophysiology and management of gastrointestinal symptoms during physical exercise, and the role of splanchnic blood flow. Aliment Pharmacol Ther. 2012;35(5):516-28. doi:10.1111/j.1365-2036.2011.04980.x

39. Eysteinsdottir T, Gunnarsdottir I, Thorsdottir I, Harris T, Launer LJ, Gudnason $\checkmark$, et al. Validity of retrospective diet history: assessing recall of midlife diet using food frequency questionnaire in later life. J Nutr Health Aging. 2011;15(10):809-14.

40. Lundy B. Dietary studies of athletes: an interview with sports dietitian Bronwen Lundy. Interview by Louise M. Burke. Int J Sport Nutr Exerc Metab. 2006;16(2):226-8.

41. Selected issues for nutrition and the athlete: a team physician consensus statement. Med Sci Sports Exerc. 2013;45(12):2378-86. doi:10.1249/MSS. 0000000000000174

\section{Submit your next manuscript to BioMed Central and we will help you at every step:}

- We accept pre-submission inquiries

- Our selector tool helps you to find the most relevant journal

- We provide round the clock customer support

- Convenient online submission

- Thorough peer review

- Inclusion in PubMed and all major indexing services

- Maximum visibility for your research

Submit your manuscript at www.biomedcentral.com/submit 